\title{
Ideology and Institutional Transformation
}

\author{
Dayi GUI
}

Hubei university of police, Wuhan, China

\begin{abstract}
As an informal institution, ideology can reduce transaction costs and stimulate economic growth during economic development. In the institutional transformation, ideology helps to promote mutual transformation and development of formal and informal institutions. The achievements of Chinese economic growth and institutional transformation owe to ideological construction of the development outlook centered on economic growth and it is because of ideology that local governments are inspired to make institutional innovations constantly and push economic development. To face the reform and development in the future, it will be an effective policy to reinforce the ideological authority.
\end{abstract}

KEYWORD: ideology; local governments; institutional innovation; institutional transformation

\section{INTRODUCTION}

In Marxist analytical framework, ideology, as a component of superstructure, is enslaved by and also reacts up on economic base and it constitutes a part of political life. However, in-depth discussion about the mechanism, approaches and methods how ideology reacts up on the economic base is rarely touched. Douglas North is the first to introduce ideology as a variable into the analytical framework of long-term economic development and explained differences in economic development of different economic entities.

This paper takes the institutional transformation within over 30 years since reform and opening up as background to observe and study the ideological origin of institutional transformation at each stage and analyze the mechanism how ideology acts on institutional transformation. It is thought that the ideological reform of the leadership decides the orientation of institutional supply and local governments serve as the first action group and do experiments constantly, while their success of institutional innovation will reinforce the ideological authority of leadership and strengthen the process of institutional transformation.

\section{IDEOLOGY AS INSTITUTION}

When economists say "institution", they usually refer to a set of principles that governs the behavior relation between certain economic entities, i.e. institutional arrangement (Davis and North, 1994; Lin Yifu, 1994). Institutional arrangement can be divided into internal institutions and external institutions. The former is rules evolved from experience within groups, while the latter is those designed by political bodies and imposed on society. Ideology is derived from experience within groups, so it belongs to internal institutions and is characterized by strong self-discipline and selfenforcement. Ideology, together with other institutional arrangement like customs, morality, ethics and value beliefs, constitutes informal institutional arrangement and plays a vital role.

Since North introduced ideology into scope of researches on institutional economic history, his researches of formal institutions centered on property right extended to informal ones focused on ideology. North thought that ideology was an indispensable part of economic theory researches and there would be countless problems to explain modern resources allocation and historical changes if there was no a definite ideological theory, thus ideological changes and innovations were important institutional factors in economic growth. Ideology has played a very important role in economic development and institutional transformation. As Douglas North said, "we will encounter countless dilemmas to explain modern resources allocation or the capacity of historical transformation if there are no definite ideological or knowledge sociological theories." Nowadays, China 
is in the midst of transformation from planned economy system into market economy system and the economic functions of ideology are mainly manifested in the following four aspects:

Firstly, ideology has a directive function in economic institutional construction. Ideology is a set of beliefs and includes definitions of agreeable society and organization patterns. People use ideology to support or oppose the existing world order and then build new order. It is the ideology that decides what the agreeable society is, so institutions are built on ideology from the angle of rational constructivism.

The directive function of ideology for economic institutional construction lies in mutual transformation between formal and informal institutions. Ideology, as informal institution to define agreeable society and organization patterns, is stable and lasting and changes into codes of conduct when adopted by different interest parties. Ideology plays a significant institutional role to govern behaviors of different interest parties and legalized and normalized ideology will become formal economic institutional arrangement. Meanwhile, after the formal economic institutions are put forward, they will become the general codes of conduct and basic values for different interest parties as implemented with authority of governments and then internalized to the social ideology.

Secondly, ideology can reduce transaction costs in economic operation and institutional implementation costs. On one hand, ideology, as a common value belief, can correct behaviors of individuals so that opportunistic behaviors can be decreased or overcome. Successful ideological education is conducive to raise utility assessment on honest, trust, loyalty and good conscience, thus opportunistic or aberrant behaviors will be less and trust can cut transaction costs as well as costs for compulsory law enforcement and implementation of other institutions. On the other hand, ideology, as a "world outlook", reduces information and negotiation costs to reach consensus in terms of value judgments and behavior judgments between right and wrong, good and evil, beauty and ugliness, etc.

Thirdly, ideology can stimulate the economic development. Ideology, as superstructure of perception and value form abided by the society, can stimulate the confidence, passion, ambition and determination of social members to realize goals on one hand and can make the long-term group goal more attractive and persuasive and supported by all members who are willing to sacrifice the short-term interest for the long-term group goal on the other hand. It is possible to develop economy through ideological construction and struggle. Marx ever said, "Theories will change into great material strength once mastered by the public" and it can be seen that it is not just a popular slogan but practice of most advanced elements to devote themselves into business activities for national or collective interests rather than personal interests at 30 years ago. Before reform and opening up, the achievements of economic construction in China have close relation to ideological stimulation.

Fourthly, ideology can be converted into capital. Ideology is a key factor to decide social capital and the conversion method is to impose requirements on ideological believers, that is to say, make they fight for vested interests or interests of some persons but neglect their own interests. Fukuyama thought culture was significantly correlated with economy in one country and he distinguished three types of societies and their economic conditions, i.e. culture of high trust level, culture of low trust level and culture lack of trust level (Francis Fukuyama, 2001), and the core of cultural category in his researches was exactly ideology.

\section{IDEOLOGY AND INSTITUTIONAL TRANSFORMATION}

Institutional transformation refers to the institutional replacement, transition and transaction process and it can be deemed as the substitution process of an institution with a more effective institution or interpreted as the production process of a more effective institution. Institutional transformation falls into two types: induced institutional transformation and imposed institutional transformation. The former refers to institutional arrangement and rights definition decided by subjects to maximize their benefits under given constraint conditions and is topdown, while the latter refers to institutional innovation organized by the government through administrative, economic and legal means and it matches the centralized decision-making system of one country with undeveloped market economy and strong national strength. As an informal institution, ideological is promoted by the government from top to down or by public from bottom to top, but the latter means takes quite a long time.

Chinese reform process appears as the government-oriented institutional transformation and institutions, which help to bring about agreeable social order by defining the interpersonal relationship, are deemed as operational rules under the specific ideology. Institutions are set down by the Party and management level of one country, so they change as the ideological changes of the management level. Only if the ideology of major decision makers' change or the distribution of 
ideology in society changes, will the institutions change correspondingly. The Chinese institutional transformation since reform and opening up is a process that the government carried out market economy supply constantly with the guidance of the management level's ideology.

It is generally considered that the Third Plenary Session of the Eleventh Central Committee held in November 1978 is the beginning of Chinese economic reform, but it is actually the discussion about truth criterion that opened the door towards economic reform when the ideological line of "seeking truth from facts" was re-established and ideological foundation was laid by denying "two whatevers" and resolutely stopping slogans like "continuing reform under dictatorship of the proletariat" and "taking the class struggle as key link", etc. Afterwards, the institutional transformation was characterized by evolutionary features since there were no clear objectives for a time. In rural areas, farmers initiated reform top-todown as encouraged or tacitly permitted by local governments and the production responsibility system of contracting production quotas to each household was finally established. The success of rural reform, increment of crop yield and alleviation of food supply and demand relation made the leadership who showed skepticism changed ideas. In 1982, the Twelfth National Party Congress put the economic system as "planned economy supplemented by market regulation" and "Planned economy based on public ownership implemented and planned production and circulation is the mainstay of national economy. Meanwhile, it is allowed that production and circulation of some products are not planned but regulated by market, that is to say, the nation lines out a certain scope according to specific circumstances of different times to let value rule play a regulative role automatically". On the Third Plenary Session of the Twelfth Central Committee in 1984, the concept of "planned commodity economy based on public ownership" was proposed. The concept of socialist commodity economy was confirmed by the leadership for the first time, which plays a very important role to push market-oriented economic reform. At that time, the consensus of economic reform was reached. In the same year, the urban reform broke the ice and specific policies and measures like double-track pricing system and contract system were formulated and publicized to expand output. The success of economic reform stimulated the ideological transformation of the leadership. In 1987, the theory of "preliminary stage of socialism" was formed and the ideological line of "one focus and two basic points" was decided on the Thirteenth National Party Congress. One focus refers to economic construction and the central task of CPC is to do well in economic construction, which marks that the development outlook centered on economic growth is formed.

The second stage of Chinese economic reform is marked by the Fourteenth National Party Congress in 1992 when the goal to establish socialist market economy was set down for the first time, which was officially put forward to build socialist market economy system from the institutional level. This institutional innovation was right the process of fierce ideological struggle and consensus of the leadership. Due to the overheated economy in late 1980s and political disturbance in 1989, the central government was rather conservative for the relation between planned economy and market. In December 1990, Suggestions of the Central Committee of the Communist Party of China about Formulating Tenyear Program and 85 Plan of National Economic Development emphasized that "market regulation is more important than planned regulation" and highlighted the role of plan and planned economy but status of market economy dropped. Under the circumstances, Deng Xiaoping made an inspection tour to the Sothern China. Aimed at the ideological trend that denied market economy and upsurge of factors of planned economy at the double-track system, he delivered an important speech, "Planned economy or market economy is not the essential difference between socialism and capitalism. Planned economy is socialism and the capital society also has plan; market economy is capitalism and the socialist society also has market. Plan and market are both economic means". Consequently, the ideological constraint that puzzled people for a long time was completely got rid of and it marked the formation of socialist market economy theory. In November 1993, the Third Plenary Session of the Fourteenth Central Committee verified and passed Decisions of the Central Committee of the Communist Party of China about Problems in Establishing Socialist Market Economy (Decisions for short) and the Decisions systematized and specified the goals and basic principles of restructuring economic system, which were the overall plan for China to establish socialist market economy system. As the reform and opening up deepened and great achievements were made in socialist market economy construction, people's understanding about socialism and market economy was deepening continuously.

From the previous two stages, it can be found that the Chinese reform owed to the great ideological changes of CPC. The discussion of truth criterion initiated the Chinese economic reform in 1978. The socialist market economy theory was established in 1992, which pushed the sustainable marketization 
reform in 1990s and also obtained substantial growth of national economy, thus the development outlook centered on economic growth gradually became the core ideology. According to the interactive transformation between ideological change and institutional transformation, it can be seen that all meaningful reforms all start from ideological reform and the reform will actually begin only if the ideological change makes a breakthrough and is recognized by the leadership of the central government and accepted by governments of all levels and the society. Therefore, the transformation from planned economy to market economy would be impossible if the socialist ideological change didn't come true.

\section{CONCLUSIONS}

The over 30 years' course of Chinese reform and opening up has verified the general institutional transformation process, i.e. ideological reforms give rise to formation of basic economic systems firstly, and local governments inspired by the ideology try to promote institutional innovation, improve policy systems and spur economic growth, and finally constant economic growth in turn corrects and reinforces the ideological instruction. Ideological construction is at the forefront of institutional construction all the time, so it is important to strengthen ideological construction and reinforce the stimulating and constraint functions to face the reform goals at the next stage. Firstly, the ideological connotation of harmonious society shall be enriched. The efficiency-oriented development outlook becomes justice-centered, which does not only meet value requirements of harmonious society but can also provide judgment basis for designing new institutions. Secondly, the constraint of ideological authority on local governments shall be reinforced. Local governments inspired by the development outlook centered on economic growth have chased after rapid growth of local economic aggregates for a long time and even undermine other goals, which goes against values of harmonious society. As a result, the awareness of scientific development and harmonious development shall be strengthened. In a word, ideological construction will play a vital role to face in-depth reform and increasing difficulty.

\section{REFERENCES}

[1] North, D.C., and Thomas, R. P:The Rise of the Western World: A New Economic History, Cambridge University Press. 1973

[2] North, Douglass: Institutions, Institutional Change and Economic Performance, Cambridge: The University Press. 1990

[3] Bromley, D.W: "Economic Interests \& Institutions-the conceptual foundations of public policy", Basil Blackwell, New York and Oxford, UK. 1989

[4] Migdal, Joel S. and Atul Kohli and Vivienne Shue (eds.), State Power and Social Forces: Domination and Transformation in the Third World/New York: Cambridge University Press, 1994 